\title{
"Handicraft small enterprises as an instrument for rural economic growth and poverty eradication"
}

\begin{tabular}{|c|c|}
\hline AUTHORS & $\begin{array}{l}\text { Oluwayemisi A. Abisuga-Oyekunle (D https://orcid.org/0000-0001-7738-3132 } \\
\text { R http://www.researcherid.com/rid/M-9372-2018 } \\
\text { Mammo Muchie } \mathbb{D} \text { https://orcid.org/0000-0003-4831-3113 }\end{array}$ \\
\hline ARTICLE INFO & $\begin{array}{l}\text { Oluwayemisi A. Abisuga-Oyekunle and Mammo Muchie (2020). Handicraft small } \\
\text { enterprises as an instrument for rural economic growth and poverty eradication. } \\
\text { Problems and Perspectives in Management, 18(4), 25-36. } \\
\text { doi:10.21511/ppm.18(4).2020.03 }\end{array}$ \\
\hline DOI & http://dx.doi.org/10.21511/ppm.18(4).2020.03 \\
\hline RELEASED ON & Thursday, 29 October 2020 \\
\hline RECEIVED ON & Wednesday, 06 May 2020 \\
\hline ACCEPTED ON & Tuesday, 22 September 2020 \\
\hline LICENSE & $\begin{array}{l}(c) E Y \text { EY } \\
\text { This work is licensed under a Creative Commons Attribution } 4.0 \text { International } \\
\text { License }\end{array}$ \\
\hline JOURNAL & "Problems and Perspectives in Management" \\
\hline ISSN PRINT & $1727-7051$ \\
\hline ISSN ONLINE & $1810-5467$ \\
\hline PUBLISHER & LLC "Consulting Publishing Company "Business Perspectives" \\
\hline =OUNDER & LLC "Consulting Publishing Company "Business Perspectives" \\
\hline
\end{tabular}

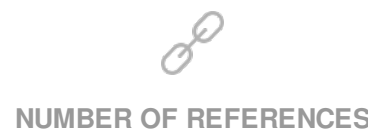

33
NUMBER OF FIGURES

3
NUMBER OF TABLES

7

(C) The author(s) 2021. This publication is an open access article. 


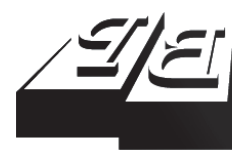

\section{BUSINESS PERSPECTIVES}

LLC "CPC "Business Perspectives" Hryhorii Skovoroda lane, 10, Sumy, 40022, Ukraine www.businessperspectives.org
Received on: $6^{\text {th }}$ of May, 2020 Accepted on: $22^{\text {nd }}$ of September, 2020 Published on: 29th of October, 2020

() Oluwayemisi A. Abisuga-Oyekunle, Mammo Muchie, 2020

Oluwayemisi A. Abisuga-Oyekunle, DBA, Postdoctoral Research Fellow, Department of Industrial Engineering, Faculty of Engineering and the Built Environment, Tshwane University of Technology, South Africa. (Corresponding author)

Mammo Muchie, Ph.D., NRF/ DST South African Research Chair Professor, Department of Industrial Engineering, Faculty of Engineering and the Built Environment, Tshwane University of Technology, South Africa.

\section{HANDICRAFT SMALL ENTERPRISES AS AN INSTRUMENT FOR RURAL ECONOMIC GROWTH AND POVERTY ERADICATION}

\begin{abstract}
In South Africa, exploiting economic opportunities in the handicraft sector could create livelihood and employment for ordinary citizens living in rural areas. The potential contribution of handicraft small enterprises to sustainable livelihoods and poverty alleviation is yet to be fully exploited. It is also regarded as a sector with great growth potential, but the degree of support provided to the handicraft sector is low. The study aims to evaluate the socioeconomic factors influencing the viability of handicraft small businesses operating in KwaZulu-Natal. Data collection was drawn from a stratified random sample of 196 handicraft practitioners operating in different areas of KwaZuluNatal Province with a structured questionnaire. Data analysis was performed with the STATA statistical package. The results obtained from the study have shown that 84 enterprises (42.86\%) were not viable, whereas 112 of the 196 handicraft enterprises (57.14\%) were viable. The percentage of overall correct classification for this procedure was equal to $77.96 \%$. Percentage sensitivity for the fitted logistic regression model was equal to $60.71 \%$. Percentage specificity for the fitted logistic regression model was equal to $82.14 \%$. The p-value obtained from Hosmer-Lemeshow goodness-of-fit test was equal to $0.0884>0.05$. This indicates that the fitted logistic regression model is fairly well reliable. The findings from the analysis showed that two factors significantly influenced the viability of handicraft enterprises. These two factors were the belief that handicraft business could sustain the handicraft practitioner, and the level of support for handicraft businesses from non-governmental organizations is decreasing.
\end{abstract}

Keywords

entrepreneurship, enterprises, livelihood, employment, sustainable development

\section{JEL Classification $\quad$ L20, I30}

\section{INTRODUCTION}

Unemployment is a huge socioeconomic problem in South Africa. Regardless of the potential role of small enterprises to speed up job creation and developing countries' economic development, quite a few bottlenecks affect these enterprises to reach their full potential. In KwaZulu-Natal Province, several challenges continue to impede the sustainable growth and development of handicraft practitioners and small enterprise in general to advance the provincial economic growth and prosperity. Although handicrafts have cultural significance and economic value to poor rural households, the sector has been neglected by most governmental policymakers. In South Africa, exploiting economic opportunities in the handicraft sector could create employment and livelihood for ordinary people who live in rural parts of the country and possess a low level of technological skills. As such, it has become prudent to explore economic sectors such as handicrafts to reduce abject poverty among the masses in most rural parts of South Africa. Oyekunle (2017) also found that appropriate creative skills should be promoted at the grassroots level by running community-based empowerment initiatives to reduce poverty among 
the rural population of South Africa. The handicraft sector in South Africa has the potential for growth, development, and job creation for the unemployed youth (Nyawo \& Mubangizi, 2015). Hence, this study aims to identify and evaluate socioeconomic factors influencing the viability of handicraft products. In South Africa, exploiting the handicraft sector as a means of economic growth opportunities could be a means of livelihood and employment creation for ordinary citizens who live in rural parts of the country and possess a low level of technological skills.

The study had a specific research objective: to evaluate the economic potential of handicrafts produced by small enterprises in the Midlands of KwaZulu-Natal. This research argued that providing appropriate sector-specific support to poorly trained and poorly equipped operators of handicraft small enterprise is a key requirement for poverty alleviation and rural economic growth in South Africa. Hence, assisting small enterprises in the handicraft sector is helpful and beneficial for the national economy. As South African handicraft enterprises' business skills increase, they have the vision of creating an advanced impact on both rural and urban economies by producing a high number of first-hand jobs (Oyekunle \& Sirayi, 2018a). The study assessed the handicraft small enterprises' economic potential in the KwaZulu-Natal Midlands (an inland area of KwaZulu-Natal that lies between Pietermaritzburg and Drakensberg mountain range).

\section{LITERATURE REVIEW}

\subsection{The handicraft small enterprises and KwaZulu-Natal Province}

KwaZulu-Natal Province is between the great Drakensberg Escarpment and the Indian Ocean, occupying $8 \%$ of the South African geographical area. In 1994, the KwaZulu-Natal Province, also known as KZN, was created when the Natal Province was merged with the Zulu Bantustan of KwaZulu (Place of the Zulu, in Zulu). The rural area Midlands Meander was used as the location of the survey for this study. Handicrafts reflect the urban region's cultural mix. Many markets in rural areas have regular open-air markets where the arts and handicrafts are displayed for sale. Several arts and handicraft routes are widely known around Midlands Meander, i.e., 'Battlefield', 'Drakensberg', 'Newcastle,' and 'Valley of 1,000 hills'. These four locations in KwaZuluNatal Province were used for the present study. Today they offer customers exciting product experiences like ceramic pots, unfired clay, beadwork, and wood carvings and are among the most popular handicraft pieces available, while the city has also produced many fine artists whose artworks hang in galleries around the country (Buss, 2018). However, the Zulu Kingdom itself is proud of several prominent galleries, such as the Pietermaritzburg's Durban Art Gallery and Tatham Art Gallery.
There is no consistent descriptive definition of a small enterprise. The understandings of small enterprises differ between countries and are reviewed frequently by the institution's backing its development and cantered on specific measures determined by the economic development of a country. For instance, some countries scale small enterprises based on the numbers of full-time employees and certain sizes of sales (Hashim, 2012) or shareholders' fund (Gecse, 2013). Records on the number of South African small enterprises remain unelaborated. While FinScope (2010), a South African Small Business Survey, makes it known that small enterprises deliver an extra estimated 6 million employment opportunities separately from the 11.6 million small enterprise proprietors in South Africa.

The National Small Business Amendment Act 26 of 2003 1(e) of South Africa defines small enterprise to entail a distinct and separate business unit, comprising cooperative enterprises, mainly practised in any subsector or sector of the economy, which is managed by one or more owner, categorized as micro, very small, small, or medium enterprise. Hence, the Department of Trade and Industry (DTI) (2008) describes small enterprises as including occasional home-based evening jobs or survivalist hawking enterprises.

Even though every enterprise is faced with some forms of challenge all through their operations, 
there are times that smaller firms are faced with greater challenges compared to larger firms. However, the size increase of an enterprise relates positively to its rate of survival. Some of the challenges faced by small enterprises are directly related to their limited resources, such as lack of skilled labor, access to credit and raw materials, while others are faced with the problem of a small firm owner being a generalist (Mutandwa, Teremwa, \& Tubanambazi, 2015). Small enterprises perform a great role in employment creation, developing skills, competitiveness, stability, and ensuring economic growth, requiring urgent attention.

\subsection{Contribution of handicraft to sustainable livelihood}

Research in Jordan (Mustafa, 2011), Mexico (Sánchez-Medina, Corbett, \& Toledo-López, 2011), Thailand (Chudasri, Walker, \& Evans, 2012), AsiaEurope (Sreekanta, 2008), Scotland (Ferraro, White, Cox, Bebbington, \& Wilson, 2011), India (Wood, 2011), and developing countries (Zargham, 2007) has disclosed the potentials of developing handicraft industries as a means of sustainable development and source of livelihood. According to Kuhlman and Farrington (2010), sustainability is defined as a state of concern, which the totality of man-made and natural resources stays at any rate of constant in the predictable future to protect the well-being of future generations from falling. As stated by Annamma, John, Alladi, Jeff, and Ricky (2012), both sustainable development and handicraft are elaborately related to the way human beings build and understand life (Ferraro et al., 2011) with social relations and culture, and with the livelihood and broader economic opportunities. Oyekunle (2017) acknowledged that irrespective of its economic significance, the creative products likewise produce non-monetary significance, contributing to attaining people-centered sustainable development.

Handicrafts have been acknowledged as a vital strategy for sustainable development that can solidify employment opportunities, specifically in the rural regions, by contributing to the national economy. In South Africa, the government has also recognized handicraft as contributing to sustainable development, economic growth, employment opportunities, and conforming to the strategic plan
(Oyekunle \& Sirayi, 2018a). Therefore, there is an urgent need to integrate the traditions with handicraft product management (for instance, customers, materials, skills, stakeholders, retails, markets, etc.) to address effective sustainability plans.

South African Department of Art and Culture points out that the Arts, Social Development, and Youth Program (ASDY) is working towards greater handicraft access for all communities, particularly marginalized groups, and these groups include (Walker \& Donaldson, 2010) disadvantaged women, young adult at risk, families in crisis, children without access to early childhood development initiatives, and people with disabilities. If properly focused on and well organized, the handicraft sectors can generate many jobs quickly. Therefore, further research into sustainability is most needed, as handicrafts are confirmed to be significant to a sustainable livelihood in the $21^{\text {st }}$ century, to make a strong relationship between handicrafts and sustainable development.

\subsection{Entrepreneurship and economic growth}

In developing economies, entrepreneurial activity is crucial owing to important socioeconomic issues of controlling growing poverty (Oyekunle \& Sirayi, 2018b). Entrepreneurship is important for the economic growth of private sectors in Africa. Thus, its consequence concerning the African countries' economic success is more concentrated on solving problems that hinder the socioeconomic well-being of the people (Brennan \& Fickett, 2011). Reynolds, Camp, Bygrave, Autio, and Hay (2001) put on that if the general national framework conditions are properly developed and the new firms' international competitive position was improved, they will create growth for the entrepreneurial processes in the national economy. The entrepreneurial processes provide another growth mechanism by highlighting the role of growth and new firms. This entrepreneurial framework condition is related to, but different from, the general national framework condition. The national economic growth and entrepreneurial activity tend to happen together, the connection between them is positive, but not strong, and this depends on the nature and the country analysis of the entrepreneurial activity. 
Furthermore, two views of the entrepreneurial sector are described - the people's capacity to initiate new firms and the emergence of opportunities. This is believed to contribute to change and instability among jobs and firms, blending the business sector. Consequently, churning is believed to contribute to national economic growth. Herrington, Kew, and Mwanga (2016) show a complete scale of the numbers of individuals engaged in the churning pool of employment opportunities and indicating its potential for economic and employment significance. However, the role small firms play in the job creation process has remained controversial. Many politicians and economists now notice the positive effect of entrepreneurship on employment and the growth of GDP. Additionally, the data obtained from South Africa illustrate that entrepreneurial activities and employment creation are more connected to the age of the enterprises more than to their size.

\subsection{Impacts of handicrafts on the rural economy}

The economic impact of handicraft on rural and urban livelihoods has not been researched in South Africa. Still, the government has overseen many projects that have sought to tackle poverty through craft developments, which could also bring development into areas where the levels of poverty were highest. Hence, the NGOs, provincial government, and private organizations need to be assisted in delivering the type of infrastructure and services support required to promote handicraft sectors by creating a training program and community-based projects (Oyekunle, 2014).

However, Oyekunle and Fillis (2016) opined that there is an inadequate number of researches regarding the handicraft sector's economic contribution, and they suggested that the sector should be more developed and evolved. Statistical analysis of surveys confirms that many handicraft enterprises are located in rural areas and contribute significantly to the rural economy. It is greatly important to highlight this worth because, generally, rural businesses are not valued for their contribution to the national economy. What is needed is a sectoral specific and the establishment of marketing, resulting in long-term growth, rather than survival under ever-tightening government-funding budg- ets (McIntyre, 2001). Thus, handicraft small enterprises promote understanding and awareness among different cultures, create an irreplaceable informal sector, create opportunities for the small entrepreneur, and protect the environment and generate better economic connections.

In South Africa, most of the crafters travel to sell their wares, which has wide-ranging benefits for the economy. Crafters meet up with each other at festivals and shows, barter with each other for goods, exchange ideas, or for those who can afford it, purchase other crafter's goods for resale at other retail locations. They ploughed back the money earned in the local economy through their expenses, e.g., food, accommodation, petrol/transport, entertainment, etc. Oyekunle and Sirayi (2018b) affirm a strong flow of goods and cash are achieved in South Africa due to all these activities. Hence, traders who travel all over Africa in search of craft products encourage trade in many rural communities, and they are continually searching for transactions with which they can earn more profit.

McAuley and Fillis (2005) express that it is important to see these enterprises' contribution as part of a "bigger picture". Sarma (2008) contributes that the level of impact of the handicraft activities on the economy and tourism sector is not restricted to an ordinary inter-sectoral connection and other factors that influence these sectors' level of impact on the national and local economy. The handicrafts are significantly in different social contexts. Still, in a country like South Africa, handicraft activities in the rural area have been an important aspect of everyday life and are a popular cultural activity that is part of the general economy, and provide ample employment opportunities (Aigbavboa \& Thwala. 2014).

\section{AIMS AND RESEARCH HYPOTHESES}

Although several economic policies have been implemented in various forms in South Africa, they have failed to generate many employment opportunities for the unemployed and unskilled masses. As such, it has become prudent to explore economic sectors such as handicrafts to alleviate abject pov- 
erty among the masses in most rural parts of South Africa. The study aims to evaluate socioeconomic factors influencing the viability of handicraft small businesses operating in KwaZulu-Natal. Therefore, this research addressed the gap by assessing the socioeconomic potential of the handicraft industry. Further, the study addressed the gaps identified with knowledge, cutting-edge handicraft marketing and production as a socioeconomic development strategy for sustainable livelihood.

A research hypothesis is an assumption that needs to be tested for validity by collecting empirical evidence. Empirical evidence needs to be collected by using appropriate methods and materials of study. As part of this study, two research hypotheses of importance to the handicraft sector of the KwaZulu-Natal Province were tested at $5 \%$ level of significance. These two research hypotheses are as follows:

Research hypothesis 1: The viability of handicraft enterprises is not influenced by the firm belief of handicraft entrepreneurs that their business could sustain them.

Research hypothesis 2: The viability of handicraft enterprises is not influenced by the government's level of support provided to handicraft entrepreneurs.

\section{METHODOLOGY}

The study uses a quantitative method of data collection and analyses. The study design is cross-sectional and descriptive. A stratified random sampling technique was used to select a sample size of 196 handicraft entrepreneurs from the various parts of the Midlands of KwaZulu-Natal. A pre-tested, structured, and validated questionnaire of the study was used for collecting data as part of the quantitative part of the study. Hence, the research question is how big the economic potential of handicrafts produced by small enterprises in KwaZulu-Natal's Midlands is?

\subsection{Sample size of the study}

This study used a stratified random sample of 196 handicraft entrepreneurs selected from the midlands of KwaZulu-Natal Province. Face validity
(Levy \& Lemeshow, 2013) was ensured by conducting a pilot study of size $n=5$ respondents. Internal reliability and consistency were ensured using the Cronbach Alpha test (Levy \& Lemeshow, 2013).

The initial sample size of the study is denoted by $n_{0}$, and is determined using the formula shown in Equation (1):

$$
n_{0}=\frac{Z_{1-\frac{\alpha}{2}}^{2} \cdot P(1-P)}{d^{2}} .
$$

In most cases, the value of $\alpha$ is fixed at the 5\% level.

$\alpha \rightarrow=0.05-$ level of significance

$\alpha \rightarrow Z_{1-\frac{\alpha}{2}}=Z_{1-\frac{0.05}{2}}=Z_{1-0.025}=Z_{0.975}=1.96-$ value of a standard normal random variable at the $\alpha=0.05$ level of significance

$d=0.048-$ margin of error.

$P$ is the proportion of people who have adequate skills in handicraft business. There are no estimates in the relevant literature for the Midlands of KwaZulu-Natal Province. Thus, the value of $P$ is fixed at $50 \%=0.50$.

The final study sample size is given in Equation (2):

$$
n=\frac{n_{0}}{1+\frac{n_{0}}{N}} .
$$

In Equation (2), $n_{0}$ the study's initial sample size $N$ denotes the study's population size. It was estimated that at least 1,000 handicraft entrepreneurs in the Midlands were at the time of the study. Thus, $N=1,000$. There was no sampling frame or the list of all handicraft entrepreneurs operating in the Midlands at the study time. The size of the population $(N)$ had to be estimated by conducting simple random sampling techniques and eye inspection at the site of study.

Using the Equation (1) values, the initial study sample size $n_{0}$ becomes equal to 212 . 
Using the value of $n_{0}$ in Equation (2), the final study sample size becomes equal to 196 .

Using the above values, the study sample size was equal to 196 handicraft enterprises operating in KwaZulu-Natal Province. For a socioeconomic survey, a sample of size 196 is large enough, according to Levy and Lemeshow (2013). The geographic zones (East, West, South, North, and Central regions of the Midlands of KwaZulu-Natal Province) were used for stratification.

\subsection{Data collection}

Data were collected from each one of the 196 handicraft enterprises in KwaZulu-Natal Province on a total of 69 socioeconomic indicators that are known to affect the degree to which handicraft enterprises are profitable. Data were collected from each respondent of the study by using a pre-tested, structured, and validated questionnaire of study consisting of 69 indicators of viability in handicraft enterprises. A 5-point ordinal scale was done by using measurements of perceptions.

\subsection{Data analysis}

A quantitative method of data analysis was used for this study. The statistical package used for data entry and analysis was STATA version 14 (STATA Corporation, 2015). According to Simpson (2015), the following statistical methods of data analyses were used for conducting multivariate statistical data analyses for the study: frequency tables for categorical variables of the study with results represented in bar charts and pie charts.

\subsection{Dependent variable of study $(Y)$}

The dependent variable of the study was an indicator of viability of handicraft business. As such, this study's dependent variable was dichotomous variable (i.e., a variable which can have only two possible values). The dependent variable of the study $(Y)$ had two possible values.

\section{$Y=\left\{\begin{array}{l}1 \text { if handicraft bu } \sin \text { ess is not viable, } \\ 0 \text { if handicraft bu } \sin \text { ess is viable. }\end{array}\right.$}

$X_{1}, X_{2}, \ldots X_{k}$ are explanatory or independent variables that affect the viability of handicraft business.

\section{RESULTS}

In this section, the results obtained from frequency tables and logit analysis were presented. The variables of the study are all categorical. As such, frequency tables are ideal for summarizing the 196 respondents who participated in the study and their general characteristics. Pie charts and bar charts were used in some cases for providing graphical depictions. This study shows the viability of the 196 handicraft enterprises that were selected for the study from KwaZulu-Natal Province, and 112 of the 196 handicraft businesses in the study (i.e., 57.14\%) were viable, whereas the remaining 84 handicraft businesses (i.e., 42.86\%) were not viable. A handicraft business is defined as viable if it has an average daily sale of R100 or more, for this study. A handicraft business is defined as non-viable if it has an average daily sale of less than R100. According to Statistics South Africa (2016), average monthly incomes that are less than R3,000 are referred to as incomes below the minimum monthly average wage.

Table 1. Summary of gender, age, and race $(n=196)$

\begin{tabular}{|c|c|}
\hline Variable of study & Number and percentage \\
\hline \multirow{2}{*}{ Gender } & Male: (44.90\%) \\
\hline & Female: (55.10\%) \\
\hline \multirow{6}{*}{ Age in years } & 20 years or less: $(2.04 \%)$ \\
\hline & $21-30$ years: (16.84\%) \\
\hline & 31-40 years: (37.24\%) \\
\hline & $41-50$ years: $(31.12 \%)$ \\
\hline & $51-60$ years: $(9.69 \%)$ \\
\hline & 61 years or more: $(3.06 \%)$ \\
\hline \multirow{5}{*}{ Race of respondents } & Black: $(82.14 \%)$ \\
\hline & White: (3.57\%) \\
\hline & Colored: (1.53\%) \\
\hline & Indian: (9.18\%) \\
\hline & Others: (3.57\%) \\
\hline
\end{tabular}

In Table 1, it can be seen that about $45 \%$ of the 196 respondents who participate in the study were male, whereas the remaining $55 \%$ of respondents were female. About $73 \%$ of respondents are between the ages of 31 to 40 years. About $31 \%$ of respondents had ages of 41 to 50 years. About $82 \%$ of the respondents were Black. About $9 \%$ of the respondents were Indian. About $4 \%$ of respondents were White. About $9 \%$ of the respondents were Indian. About $2 \%$ of the respondents were Colored. 
Table 2. Level of formal education $(n=196)$

\begin{tabular}{l|c}
\hline \multicolumn{1}{c|}{ No schooling } & $\mathbf{1 0 . 7 1 \%}$ \\
\hline Primary school & $11.73 \%$ \\
\hline Grade 11 (Standard 9) & $27.55 \%$ \\
\hline Grade 12 (Matric or Standard & $42.86 \%$ \\
10) & $2.55 \%$ \\
\hline Bachelor's degree & $1.02 \%$ \\
\hline Master's degree or above & $196(100.00 \%)$ \\
\hline Total & \\
\hline
\end{tabular}

It can be seen in Table 2, a summary of the highest and lowest level of education of the 196 participants of the study. The table presents that approximately $43 \%$ of respondents had acquired matric level education. The percentage of respondents with no schooling was about $11 \%$. About $12 \%$ of respondents had primary level education. About $28 \%$ of respondents had acquired a Grade 11 (Standard 9) education. About 3\% of respondents had a Bachelor's degree. About 1\% of respondents had acquired a Master's degree.

Table 3. Summary of percentages of artisan attributes $(n=196)$

\begin{tabular}{l|c}
\hline \multicolumn{1}{c}{ Variable of study } & Number and percentage \\
\hline Artisan training & Yes: $(15.82 \%)$ \\
\hline Handicraft as the main source of & No: $(84.18 \%)$ \\
\hline income & Yes: $(27.55 \%)$ \\
\hline Business registration & No: $(72.45 \%)$ \\
& Yes: $(12.76 \%)$ \\
\hline Handicraft production & No: $(87.24 \%)$ \\
\hline
\end{tabular}

Table 3 shows a summary of percentages of attributes such as artisan training, use of handicrafts as the main source of household income, business registration, and handicraft production by the 196 participants of the study. As shown in the table, about $73 \%$ of respondents relied on handicrafts as the main source of household-level income. About $13 \%$ of handicraft businesses were registered formally. About $74 \%$ of respondents produced handicrafts by themselves.

Figure 1 shows a summary of the places used for the production of artifacts used by 196 participants of the study. The figure shows that about $59 \%$ of the artifacts are produced at home. About $27 \%$ of the artifacts are produced at designated shops. About $14 \%$ of the artifacts are produced in homes and shops.

Table 4. Assessment of sales turnover $(n=196)$

\begin{tabular}{l|c}
\hline \multicolumn{1}{c|}{ Variable of study } & \multicolumn{1}{c}{$\begin{array}{c}\text { Number and } \\
\text { percentage }\end{array}$} \\
\hline $\begin{array}{l}\text { Sales turnover generated by handicraft } \\
\text { business in } 2016\end{array}$ & R100 or less: (88.27\%) \\
\hline $\begin{array}{l}\text { Sales turnover generated by handicraft } \\
\text { business in } 2017\end{array}$ & R100 or more: $(11.73 \%)$ \\
\hline New investment in the last five years $(92.35 \%)$ \\
\hline
\end{tabular}

Table 4 assesses the sales generated by 196 entrepreneurs who were selected for the study. The table also shows the year of business operation. The table shows that about $88 \%$ of the 196 businesses in the study had an average sales turnover of R100 or less in 2016. About $92 \%$ of the businesses had an average sales turnover of R100 or less in 2017. In the past five years, about $59 \%$ of businesses had made new investments.

About $37 \%$ of businesses were in operation from 6 to 10 years, while $31 \%$ of businesses have been in operation for about 1 to 5 years, and $13 \%$ were in operation for about 11 to 15 years, as depicted in Figure 2.

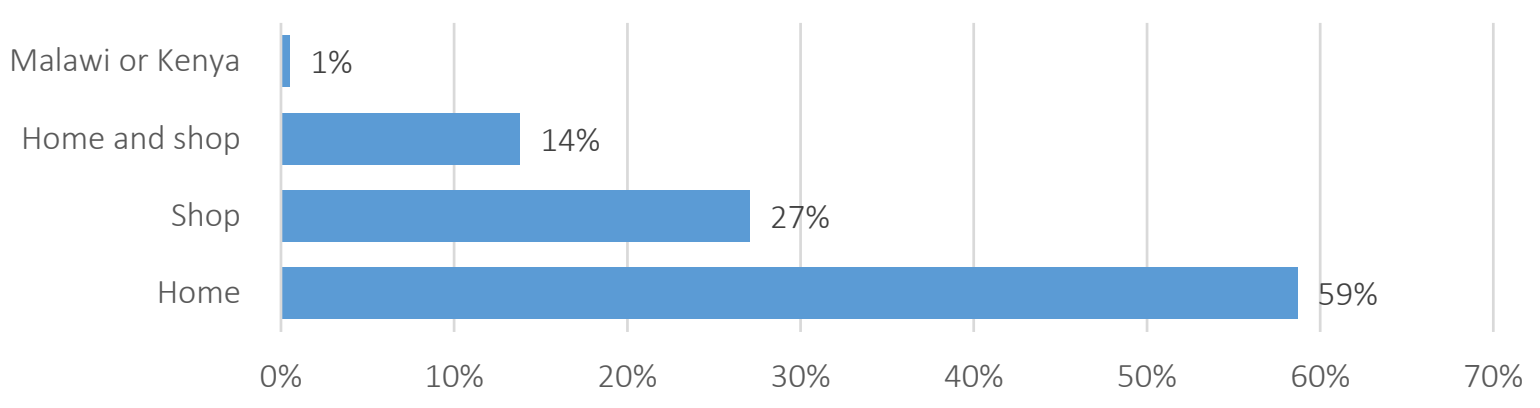

Figure 1. The places of production of artifacts $(n=196)$ 


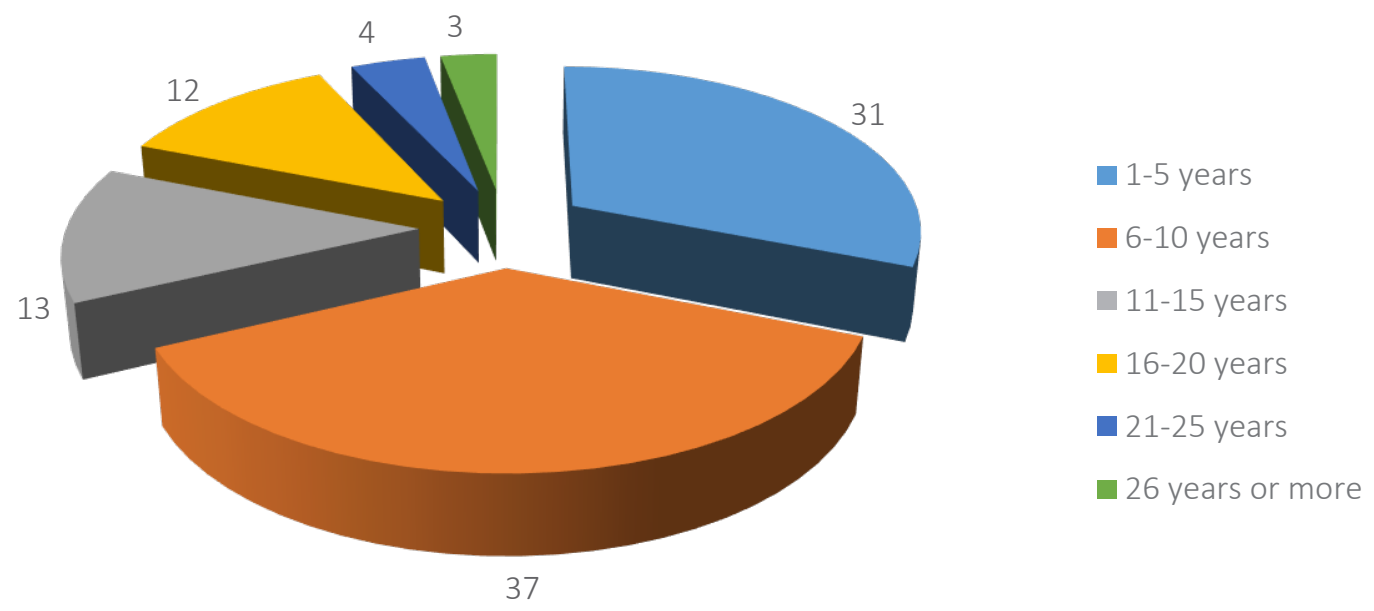

Figure 2. Number of years in business $(n=196)$

Table 5. Loan applications by respondents $(n=196)$

\begin{tabular}{|c|c|}
\hline Loan applications & Number and percentage \\
\hline \multirow{2}{*}{ Loan application attempted } & Yes: $(1.02 \%)$ \\
\hline & No: (98.98\%) \\
\hline \multirow{2}{*}{ Outcome of loan application } & Successful: (0.51\%) \\
\hline & Not successful: (99.49\%) \\
\hline \multirow{4}{*}{$\begin{array}{l}\text { Economic status of business } \\
\text { operator }\end{array}$} & Above average: $(6.63 \%)$ \\
\hline & Average: $(52.04 \%)$ \\
\hline & Below average: (38.27\%) \\
\hline & Poor: (3.06\%) \\
\hline
\end{tabular}

Table 5 shows a distribution for loan applications attempted by the 196 respondents of the study. The table shows that two of the participants $(1.02 \%)$ had attempted to secure loans at data col- lection time. The table also shows that only one of the two applications for a loan had succeeded (loan was granted by Capitec Bank). The table also shows that about $59 \%$ of entrepreneurs' economic status was average or above average. About $20 \%$ of respondents were engaged in handicraft production only.

Figure 3 shows a summary of agreements to statements read out to respondents. A 5-point ordinal scale that varies from strong agreement to strong disagreement with the statements made was used to measure the responses. The figure assesses the perception held by respondents about how worth-

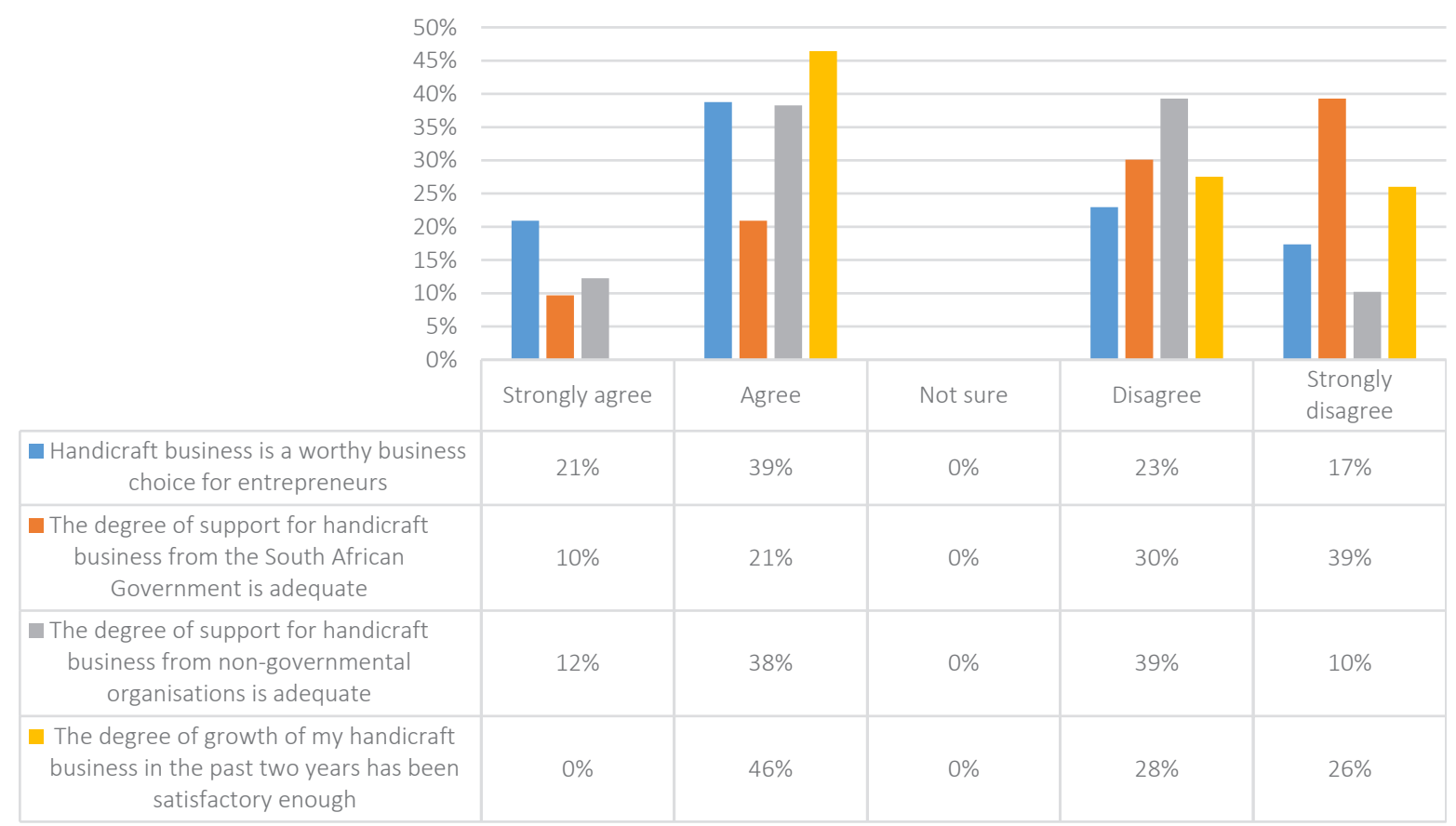

Figure 3. Perception of handicraft business $(n=196)$ 
while handicraft business is. It can be seen from the figure that about $39 \%$ of respondents believed that handicraft business is worthwhile. About 21\% of respondents believed that the South African Government's support for handicraft businesses was adequate.

\subsection{Results obtained from logit analysis}

The theoretical reliability of odds ratios estimated from logit analysis was assessed using the classification table and the Hosmer-Lemeshow goodnessof-fit test. Logit analysis (Hosmer \& Lemeshow, 2013) was used to identify key predictors of viability in the study's 196 handicraft businesses. The results showed that two predictor variables significantly influenced viability. These predictor variables were the belief that handicraft business could sustain the handicraft practitioner, and level of support for handicraft businesses from non-governmental organizations (NGOs), in decreasing order of strength.

In logistic regression analysis, the measure of effect is the odds ratio. At the 5\% level of significance, significant predictor variables are characterized by odds ratios that differ from 1 significantly, $p$-values smaller than 0.05 , and $95 \%$ confidence intervals that do not contain 1 . Table 6 shows odds ratios estimated from logit analysis. It can be seen from the table that all two predictor variables were significant at the $5 \%$ level of significance.

The percentage of overall correct classification for this procedure was equal to $77.96 \%$. Percentage sensitivity for the fitted logistic regression model was equal to $60.71 \%$. Percentage specificity for the fitted logistic regression model was equal to $82.14 \%$. The $p$-value obtained from the HosmerLemeshow goodness-of-fit test was equal to $0.0884>0.05$. This indicates that the fitted logistic regression model is fairly well reliable.

\section{DISCUSSION}

\subsection{Major findings of the study}

The study aims to evaluate socioeconomic factors influencing the viability of handicraft small businesses operating in KwaZulu-Natal. The study was conducted in the Midlands of KwaZulu-Natal Province by collecting data from a sample of 196 practitioners of handicraft enterprises using a stratified random sampling approach. The study results have shown that 84 enterprises $(42.86 \%)$ were not viable, whereas 112 out of 196 handicraft enterprises (i.e., 57.14\%) were viable. The results obtained from the analysis showed two factors significantly influenced the viability of handicraft enterprises. These two factors were the belief that handicraft business could sustain the handicraft practitioner, and the level of support for handicraft businesses from non-governmental organizations, in decreasing order of strength. Table 7 shows the list of two research hypotheses that were tested as part of the study, and the ultimate results established for the study with the decisions taken. At the 5\% level of significance, each of the two research hypotheses was tested for validity using $p$-values estimated from logit analysis. At $5 \%$ level of significance, if the $p$-value was less than $5 \%$, a null hypothesis was rejected. A null hypothesis was accepted at a $5 \%$ level of significance if the $p$-value was greater than or equal to $5 \%$.

Table 7. Summary of two research hypotheses tested as part of the study

\begin{tabular}{c|c|c}
\hline No. & $\begin{array}{c}\text { Null hypothesis is tested by } \\
\text { conducting research }\end{array}$ & $\begin{array}{c}\text { Decision } \\
\text { taken at the } \\
\mathbf{5 \%} \text { level of } \\
\text { significance }\end{array}$ \\
\hline 1 & $\begin{array}{l}\text { The viability of handicraft businesses } \\
\text { is not influenced by handicraft } \\
\text { entrepreneurs' firm belief that their } \\
\text { business could sustain them. }\end{array}$ & Rejected \\
\hline & $\begin{array}{l}\text { The viability of handicraft businesses is } \\
\text { not influenced by the level of support } \\
\text { provided to handicraft entrepreneurs by }\end{array}$ & \\
\hline & non-governmental organizations (NGOs). & \\
\hline
\end{tabular}

Table 6. Results obtained from logit analysis

\begin{tabular}{|c|c|c|c|}
\hline Factors that affect viability in handicraft businesses & Odds ratio & $p$-value & 95\% C. I. \\
\hline The belief that handicraft business could sustain the handicraft practitioner & 2.29 & 0.020 & $(1.14,4.62)$ \\
\hline $\begin{array}{l}\text { Level of support for handicraft businesses from non-governmental } \\
\text { organizations (NGOs) }\end{array}$ & 2.04 & 0.037 & $(1.04,3.98)$ \\
\hline
\end{tabular}




\subsection{Summary of findings}

Handicraft sectors provide a vital source of employment for the less privileged segments of society, specifically the rural women; the handicraft economy sometimes establishes upon traditional transferable skills which are cheap and easy to acquire, with flexible natural home-based nature that can be integrated into economic activities and household duties; handicraft can be used as an essential "entry point" into the economy, specifically for people with a poor educational background. The effectiveness of relevant developmental strategies was evaluated based on small enterprise development strategies' objectives: those focused on non-monetary economic benefits and livelihood benefits.

A review of handicrafts and poverty reduction programs, job creation, and socioeconomic benefits revealed that policies were inadequate, and a lack of implementation existed. Although the policies recognize that jobs and incomes could be derived from developing the handicraft sec- tors, there were no measured strategies to unlock small enterprises' opportunities to derive better profits and non-cash livelihood benefits from this sector. Nevertheless, handicraft small enterprises' potentials for wealth creation and poverty reduction are yet to be realized. The prospect of using handicrafts for a poverty reduction and socioeconomic development strategy is great. Yet, the present system of production is not sustainable.

Finally, government support, particularly towards the handicraft sectors' developmental needs, was seen to be absent, leading to inadequate access to resources and opportunities in the handicraft businesses. Suggestions for enhancing the capacity of rural handicraft entrepreneur's ability to develop improved financial and livelihood benefits, and partake in the communities and of the industrial activities in which they lived and operated included providing marketing and advertising support, credit facilities, training and skills development, and payment of sustainable salary and allowance to crafters.

\section{CONCLUSION}

The study sought to find out whether the sectoral and government intervention had unlocked opportunities for handicraft entrepreneurs to derive enhanced economic and business performance for crafters or not. From the analysis of the relevant literature and key findings, the study concludes, among other things, that development content and government focus of the handicrafts small enterprise and poverty reduction agenda were inadequate, and even where present, the implementation was absent. Based on the evaluation of the sustainable livelihood of crafters and their production limitations and developmental needs, this study concludes amongst others:

a) the participation of crafters with a low educational background (i.e., mostly Matric and Standard 11) in handicrafts enterprises was responsible for their low business performance;

b) illiteracy and inequalities have prohibited some crafters from participating in local training and decision making within the handicraft sector and their local markets;

c) there are socioeconomic gap differences between the handicraft entrepreneurs in KwaZulu-Natal regarding their business experience and how they cope with the obstacles.

In general, the study concludes that handicraft small enterprise strategic approaches hold the key to the successful development of cultural products and for employment creation and poverty reduction in the study area. Hence, the NGOs, provincial government, and private organizations that are not capable, but are disposed to, need to be assisted to deliver the basic support and infrastructure required for the program implementation towards the development of handicraft sectors and continuing to create more training programs (Oyekunle \& Sirayi, 2018b). 


\section{ACKNOWLEDGMENT}

South Africa SarChi Chair, Nation Research Fund and Department of Science and Technology, South African, for providing funding for this research.

\section{AUTHOR CONTRIBUTIONS}

Conceptualization: Oluwayemisi A. Abisuga-Oyekunle, Mammo Muchie.

Data curation: Oluwayemisi A. Abisuga-Oyekunle.

Formal analysis: Oluwayemisi A. Abisuga-Oyekunle.

Funding acquisition: Mammo Muchie.

Investigation: Oluwayemisi A. Abisuga-Oyekunle.

Methodology: Oluwayemisi A. Abisuga-Oyekunle, Mammo Muchie.

Project administration: Oluwayemisi A. Abisuga-Oyekunle.

Resources: Mammo Muchie.

Software: Oluwayemisi A. Abisuga-Oyekunle.

Supervision: Mammo Muchie.

Validation: Oluwayemisi A. Abisuga-Oyekunle.

Visualization: Oluwayemisi A. Abisuga-Oyekunle.

Writing - original draft: Oluwayemisi A. Abisuga-Oyekunle.

Writing - review \& editing: Mammo Muchie.

\section{REFERENCES}

1. Abisuga-Oyekunle, O. A., \& Fillis, I. (2016). The Role of Handicraft Micro-Enterprises as a Catalyst for Youth Employment. Creative Industries Journal, 10(1), 59-74. Retrieved from https://www.researchgate.net/ publication/310474492_The role_of_handicraft_micro-enterprises_as_a_catalyst_for_youth employment

2. Aigbavboa, C. O., \& Thwala, W. D. (2014). Challenges facing black owned small and medium handicraft companies: A case study of Nelspruit- Mbombela Municipality, South Africa. Journal of Economics and Behavioural Studies, 6(10), 771-778. Retrieved from https://ideas.repec.org/a/rnd/ arjebs/v6y2014i10p771-778.html

3. Annamma, J., John, F. S., Alladi, V., Jeff, W., \& Ricky, C. (2012). Fast Fashion, Sustainability, and the Ethical Appeal of Luxury Brands. Fashion Theory, 6(3), 273-296. Retrieved from https:// www.researchgate.net/publication/261737125_Fast_Fashion_ sustainability_and_the_ethical_appeal_of_luxury_brands
4. Brennan, L., \& Fickett, D. (2011). Developmental entrepreneurship in Sub-Saharan Africa. Assessing financial and social returns (IIIS Discussion Paper, No. 386). Retrieved from https://books. google.com.ua/books/about/ Developmental_Entrepreneurship_in_Sub_Sa.html?id=3J_ sxwEACAAJ\&redir_esc $=$ y

5. Buss, J. (2018). From Homestead to Roadside to Gallery: The Social Life of Late Twentieth Century and Early Twenty-First Century Zulu Ceramics (Master's thesis) University of the Western Cape.

6. Chudasri, D., Walker, S., \& Evans, M. (2013). Directions for Design Contributions to the Sustainable Development of the Handicrafts Sector in Northern Thailand. Unpublished. Retrieved from http://design-cu.jp/iasdr2013/ papers/1117-1b.pdf

7. Ferraro, E., White, R., Cox, E., Bebbington, J., \& Wilson, S. (2011). Craft and sustainable development: reflections on Scottish craft and pathways to sustainability. Craft + design enquiry, 3. Retrieved from https:// discovery.dundee.ac.uk/en/publications/craft-and-sustainable-development-reflections-on-scottishcraft-a

8. Finscope. (2010). FinScope South Africa Small Business Survey 2010. Finmark Trust. Retrieved from https://www.empowerwomen.org/ en/resources/documents/2015/4/ finscope-south-africa-small-business-survey-2010?lang=en

9. Gecse, G. (2013). Logistics practice of small and medium sized enterprises (Ph.D. Thesis). Budapest Corvinus University.

10. Hair, J. F., Black, W. C., Babin, B. J., \& Anderson, R. E. (2010). Multivariate Data Analysis: A Global Perspective. Pearson: London.

11. Hashim, F. (2012). Challenges for the internationalization of SMEs and the role of government: the case of Malaysia. Journal of International Business and Economy, 13(1), 97-122.

12. Herrington, M., Kew, P., \& Mwanga, A. (2016). Tracking entrepreneurship in South Africa: A GEM Perspective. Retrieved from http://www.gsb.uct.ac.za/ 
13. Kuhlman, T., \& Farrington, J. (2010). What is Sustainability? Sustainability, 2, 3436-3448.

14. Levy, P. S., \& Lemeshow, S. (2013). Sampling of populations: Methods and applications. John Wiley: New York. Retrieved from https://www.wiley.com/en-us/ Sampling+of + Populations $\% 3 \mathrm{~A}+\mathrm{M}$ ethods+and+Applications $\% 2 \mathrm{C}+4 \mathrm{t}$ h+Edition-p-9780470040072

15. Mcauley, A., \& Fillis, I. (2005). Careers and Lifestyles of Craft Makers in the 21st Century. Cultural Trends, 14(2), 139-156. https://doi. org/10.1080/09548960500292375

16. McIntyre, R. (2014). The Role of Small and Medium Enterprises in Transition: Growth and Entrepreneurship. UNU World Institute for Development Economics Research (UNU/ WIDER). Research for Action 49.

17. Mustafa, M. (2011). Potential of Sustaining Handicrafts as a Tourism Product in Jordan. International Journal of Business and Social Science, 2(2), 145-152.

18. Mutandwa, E., Taremwa, N. K., \& Tubanambazi, T. (2015). Determinants of business performance of small and medium size enterprises in Rwanda. Journal of Developmental Entrepreneurship, 20(1), 1-12. Retrieved from https:// ideas.repec.org/a/wsi/jdexxx/v20y2015i01ns1084946715500016.html

19. Nyawo, J., \& Mubangizi, B. C. (2015). Art and craft in local economic development: Tourism possibilities in Mtubatuba Local Municipality. African Journal of hospitality. Tourism and Leisure, 4(2), 1-15.

20. Organisation for Economic Co-Operation and Development. (2013). Local Strategies for Youth Employment Learning from Practice (No. 90161 2013). Paris.

21. Oyekunle, O. (2017). The Contribution of Creative Industries to Sustainable Urban Development in South Africa. African Journal of Science, Technology, Innovation and Development, 9(5), 607-616. https://doi.org/10.1080/20421338. 2017.1327932
22. Oyekunle, O. A. (2014). Building the Creative Industries for Sustainable Economic Development in South Africa. International Journal for Sustainable Development, 7(12), 47-72. Retrieved from https:// papers.ssrn.com/sol3/papers. cfm?abstract_id=2573089

23. Oyekunle, O. A., \& Sirayi, M. (2018a). The role of design in sustainable development of handicraft industries. African Journal of Science, Technology, Innovation and Development, 10(4), 381-388. Retrieved from https://www.researchgate.net/ publication/325887406_The_role_ of_design_in_sustainable_development_of_handicraft_industries

24. Oyekunle, O. A., \& Sirayi, M. (2018b). The role of creative industries as a driver for a sustainable economy: A Case of South Africa. Creative Industries Journal, 11(3), 225-244. https:// doi.org/10.1080/17510694.2018.1 480850

25. Reynolds, P. D., Camp, S. M., Bygrave, W. D., Autio, E., \& Hay, M. (2001). Global entrepreneurship monitor (summer report). London Business School and Babson College.

26. Sánchez-Medina, P. S., Corbett, J., \& Toledo-López, A. (2011). Environmental innovation and sustainability in small handicraft businesses in Mexico. Sustainability, 3, 984-1002. Retrieved from https://www.mdpi. com/2071-1050/3/7/984

27. Sarma, M. K. (2008). Traditional crafts of Assam: Development dynamics through touristic marketing. New Delhi: Anshah Publishing House.

28. Simpson, S. H. (2015). Creating a Data Analysis Plan: What to Consider When Choosing Statistics for a Study. The Canadian Journal of Hospital Pharmacy, 68(4), 311-317. Retrieved from https://www. ncbi.nlm.nih.gov/pmc/articles/ PMC4552232

29. South African Department of Trade and Industry. (2008). Annual Review of Small Business in South Africa 2005-2007. Final Draft. DTI: Pretoria.

30. Sreekanta, V. (2008). Linking the arts to environment \& sustainable development. Connect to Culture. Singapore: Asia-Europe Foundation.

31. Statistics South Africa. (2017) Poverty Trends in South Africa report. Retrieved from http://www. statssa.gov.za

32. Walker, J., \& Donaldson, C. (2010). Intervening to improve outcomes for vulnerable young people: a review of the evidence (Research Report DFE-RR078). Newcastle University.

33. Zargham, H. (2007). Sustainable tourism development and handicrafts in the developing world. Sustainable Development and Planning, 102, 1011-1017. Retrieved from https://www. researchgate.net/publication/269030410_Sustainable_tourism_development_and_handicrafts_in_the_developing_world 